\title{
Trading Volume Activity Memediasi Hubungan Perubahan Tarif Pajak Penghasilan Badan terhadap Return Saham
}

\author{
Ni Nyoman Sri Wardani ${ }^{1}$ \\ Fakultas Ekonomi dan Bisnis \\ Universitas Udayana, Indonesia
}

\author{
I Ketut Budiartha ${ }^{2}$ \\ Fakultas Ekonomi dan Bisnis \\ Universitas Udayana, Indonesia
}

\begin{abstract}
Surel : ssriwardani17@gmail.com
ABSTRAK

Return saham dapat menggambarkan perolehan pengembalian atas kegiatan jual-beli saham yang dilakukan oleh investor. Tingkat pengembalian yang diterima investor dapat dipengaruhi oleh faktor-faktor yang berasal dari luar perusahaan. Tujuan penelitian ini adalah untuk mengetahui reaksi pasar modal sebagai akibat adanya peristiwa perubahan tarif pajak penghasilan badan pada tahun 2020 terhadap return saham dengan trading volume activity sebagai variabel intervening. Penelitian ini berlokasi di Bursa Efek Indonesia dengan jumlah sampel 45 perusahaan yang diperoleh melalui metode purposive sampling. Pengumpulan data dilakukan melalui metode dokumentasi. Teknik analisis yang digunakan adalah analisis jalur dengan uji sobel sebagai pengujian akhir. Berdasarkan hasil pengujian, ditemukan bahwa perubahan tarif pajak penghasilan badan berpengaruh positif terhadap trading volume activity. Trading volume activity berpengaruh positif terhadap return saham. Perubahan tarif pajak penghasilan badan berpengaruh positif terhadap return saham. Dan trading volume activity mampu menjadi variabel intervening perubahan tarif pajak penghasilan badan terhadap return saham.
\end{abstract}

Kata Kunci: Return Saham; Trading Volume Activity; Perubahan Tarif Pajak Penghasilan Badan.

\section{Trading Volume Activity Mediates the Relationship between Changes in Corporate Income Tax Rates on Stock Returns}

\begin{abstract}
Stock returns can describe the acquisition of returns on the buying and selling activities of shares carried out by investors. The rate of returns are received by investor can be influenced by elements from outside the company. This study aims to determine the reaction of the capital market as a result of changes in corporate income tax rates in 2020 on stock returns with trading volume activity as an intervening variable. The location of this research is in the Indonesia Stock Exchange by using 45 samples of companies obtained through the purposive sampling method. The data is taken by documentation method. The analysis technique used is path analysis with the single test as the final test. Based on the test results, the changes in corporate income tax rates have a positive effect on trading volume activity. Trading volume activity has a positive effect on stock returns. Changes in corporate income tax rates have a positive effect on stock returns. And trading volume activity can be an intervening variable in changes in corporate income tax rates on stock returns.

Keywords: Stock Returns; Trading Volume Activity; Change in Corporate Income Tax Rate.
\end{abstract}

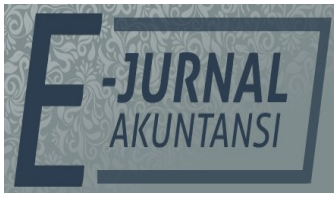

e-ISSN 2302-8556

Vol. 31 No. 8

Denpasar, Agustus 2021 Hal. 1896-1906

DOI:

10.24843/EJA.2021.v31.i08.p02

PENGUTIPAN:

Wardani, N.N.S., \&

Budiartha, I.K. (2021). Trading Volume Activity Memediasi Hubungan Perubahan Tarif Pajak Penghasilan Badan terhadap Return Saham. EJurnal Akuntansi, 31(8), 1896-

1906

RIWAYAT ARTIKEL: Artikel Masuk: 24 November 2020 Artikel Diterima: 25 Februari 2021

Artikel dapat diakses : https://ojs.unud.ac.id/index.php/Akuntansi/index 


\section{PENDAHULUAN}

Bagi investor, laporan keuangan yang dipublikasikan oleh perusahaan go public merupakan informasi yang sangat berguna terutama untuk mengambil keputusan investasi. Kebermanfaatan dari sebuah laporan keuangan dapat dilihat dari relevansinya. Chaslim \& Meiden (2018) menuturkan bahwa salah satu pengukur informasi akuntansi dikatakan relevan adalah adanya reaksi investor ketika diumumkannya suatu informasi yang dapat diamati dari adanya pergerakan harga saham di pasar modal. Ada faktor-faktor yang dapat mempengaruhi reaksi pengguna laporan keuangan dalam menilai investasi mereka seperti salah satunya perubahan tarif pajak penghasilan badan. Putri (2017) menjelaskan bahwa peraturan pajak dibuat dengan harapan agar dapat menarik minat investor dalam melakukan investasi. Panic selling yang dilakukan investor menyebabkan return atau pengembalian saham yang diterima investor berupa capital gain atau capital loss. Capital gain akan diperoleh ketika harga jual saham lebih besar bila dibandingkan dengan harga belinya, begitu pula sebaliknya, capital loss akan dialami investor bila harga beli saham lebih mahal bila dibandingkan dengan harga jualnya.

Banyak pilihan dan cara yang dapat ditempuh investor ketika menghadapi penurunan harga saham yang dimilikinya pada suatu perusahaan. Investor yang tergolong risk taker akan cenderung untuk mengambil segala resiko yang dapat dialaminya ketika menghadapi penurunan harga saham. Para risk taker umumnya berinvestasi dalam jangka pendek sehingga kemungkinan besar melakukan trading saham adalah solusi yang mereka ambil ketika harga saham mengalami penurunan. Berbeda dengan golongan investor risk averse yang akan menghindari resiko. Investor yang risk averse merupakan tipe yang konservatif, sehingga akan sangat berhati-hati dalam mengambil keputusan jangka pendek. Pergerakan harga saham yang terjadi di pasar modal Indonesia dipengaruhi oleh kondisi pasar modal Indonesia yang tergolong ke dalam tingkat efisiensi lemah (Ady, 2017), sehingga dalam mengamati reaksi pasar modal terhadap informasi perubahan tarif pajak penghasilan badan dibutuhkan harga historis atau harga masa lalu dari pergerakan saham. Gumanti \& Utami (2002) menjelaskan bahwa studi peristiwa (event studies) adalah bukti yang paling baik yang dimiliki dalam hal efisiensi sehingga untuk mengamati dampak kejadian perubahan tarif pajak penghasilan badan terhadap return saham digunakan studi peristiwa dengan tanggal event study setelah berlakunya perubahan tarif pajak penghasilan badan yakni pada tanggal 12 Mei 2020.

Perubahan tarif pajak penghasilan badan yang diumumkan melalui peraturan pemerintah pengganti undang-undang atau Perppu Nomor 1 Tahun 2020 sebagai upaya penanggulangan Covid-19 merupakan sebuah sinyal yang dikirimkan Pemerintah Indonesia kepada investor yang akan mempengaruhi kandungan informasi yang dimilikinya. Investor-investor yang jeli akan informasi yang beredar akan memanfaatkan dan bereaksi terhadap situasi yang dihadapinya. Reaksi yang ditunjukkan oleh investor dapat dilihat melalui keputusan yang diambil. Besar kecilnya reaksi pasar modal yang diakibatkan oleh adanya suatu peristiwa yang dianggap sebagai suatu informasi dapat di ukur menggunakan trading volume activity (Munthe, 2017). Densi Wulandari et al (2017) juga menjelaskan bahwa perubahan undang-undang perpajakan sebagai suatu 
informasi bagi investor akan berpengaruh terhadap trading volume activity. Berdasarkan fenomena ini, maka hipotesis penelitian yang dapat ditarik yakni.

$\mathrm{H}_{1}$ : Perubahan tarif pajak penghasilan badan memiliki pengaruh terhadap trading volume activity.

Pajak yang dikenakan terhadap perusahaan pada akhirnya akan mempengaruhi keputusan investasi dari para stakeholdernya, salah satu upaya yang dapat dilakukan oleh perusahaan untuk menjaga citra baik di mata investor adalah dengan mengimplementasikan teori stakeholders. Besarnya pengurangan pajak, waktu pengurangan pajak mempengaruhi dan merubah profitabilitas sehingga berdampak terhadap penilaian investor (Blouin et al, 2020). Hal ini sejalan dengan penelitian Delgado et al (2019) yang menyatakan bahwa pajak berefek pada keputusan investasi. Hasil penelitian Pham (2020) menunjukkan bahwa investasi meningkat pada tahun penurunan pajak dan kembali kesebelum penurunan pajak setelah peraturan tidak berlaku lagi, sedangkan Gary et al (2016) menyatakan bahwa perusahaan merespons tingkat pengembalian setelah pajak dimana pengurangan pajak membuat volatilitas menurun (Hayashida \& Ono, 2016). Reaksi yang terbentuk dari adanya informasi perubahan tarif pajak penghasilan badan tentunya akan mempengaruhi return yang diperoleh oleh investor, hal ini dikarenakan harga saham yang terbentuk merupakan tingkat harga yang menjadi kesepakatan antara penjual dan pembeli saham. Bila informasi perubahan tarif pajak penghasilan badan dianggap sebagai berita yang tidak akan menguntungkan dan dapat mengakibatkan kerugian, maka investor akan berfikir keras untuk mengambil keputusan apakah akan menjual atau membeli suatu saham. Amiruddin \& Arifin (2012) menjelaskan bahwa perubahan tarif pajak penghasilan badan memiliki hubungan yang negatif terhadap harga saham, dalam artian bila tarif pajak penghasilan badan meningkat maka return saham yang akan diperoleh investor akan menurun. Begitu pula sebaliknya, bila tarif pajak penghasilan badan mengalami penurunan, maka return saham yang akan diperoleh investor akan meningkat. Kondisi ini sejalan dengan penelitian Densi Wulandari et al (2017) yang menjelaskan bahwa kententuan-kententuan baru yang dibuat oleh pemerintah berkenaan dengan pajak akan mampu mempengaruhi return saham. Berdasarkan kondisi ini, maka hipotesis penelitian yang dapat ditarik ialah

$\mathrm{H}_{2}$ : Perubahan tarif pajak penghasilan badan memiliki pengaruh terhadap return saham.

Volume perdagangan merupakan informasi pasar bagi investor (Boonvorachote \& Lakmas, 2016). Perubahan harga saham sebagai reaksi pasar modal yang dapat diukur melalui trading volume activity merupakan cerminan dari teori sinyal yang mencerminkan keputusan yang diambil oleh investor dalam menanggapi informasi perubahan tarif pajak penghasilan badan. Heyden \& Heyden (2020) menjelaskan bahwa saham bereaksi negatif terhadap pengumuman kematian pertama akibat pandemi Covid-19 di negara tertentu sehingga investor yang rasional tidak terlalu percaya akan prakiraan pengembalian return yang besar dan kecil (Zhang et al, 2019). Trading volume activity dipicu oleh berbagai aspek seperti informasi pribadi, ketidaksepakatan di antara investor karena perbedaan pendapat yang disebabkan oleh perbedaan informasi yang dimiliki serta ketidak sabaran investor (Xu et al, 2020). Dai et al 
(2020) menjelaskan bahwa volatilitas pasar saham berpengaruh terhadap volatilitas saham. Xu et al (2019) menyatakan bahwa saham dengan asimetri return tinggi menunjukkan expected return yang rendah dan prediksi pengembalian saham sangat penting untuk menilai harga aset berupa saham yang dimiliki investor (Dai \& Zhu, 2020). Trading volume activity menggambarkan kekuatan permintaan dan penawaran dalam membetuk harga saham yang nantinya akan mempengaruhi return saham itu sendiri. Hal ini sejalan dengan hasil penelitian Taslim (2016) yang menyatakan bahwa Trading volume activity berpengaruh signifikan terhadap return saham dan penelitian Ariyani Indriastuti B. Zumrotun (2017) yang menjelaskan bahwa volume perdagangan berpengaruh positif terhadap return saham. Rzayev \& Ibikunle (2019) juga menjelaskan bahwa trading volume activity mampu untuk menjadi prediktor return saham. Berdasarkan fenomena ini, maka hipotesis penelitian yang dapat ditarik adalah.

$\mathrm{H}_{3}$ : Trading volume activity berpengaruh terhadap return saham.

Reaksi pasar modal menanggapi adanya sinyal berupa perubahan tarif pajak penghasilan badan dapat dipengaruhi oleh faktor-faktor lain di luar informasi keuangan seperti yang dijelaskan Sari (2013) yang menuturkan bahwa perubahan tarif pajak penghasilan badan memiliki pengaruh tidak langsung terhadap return saham yang diperoleh investor. Amiruddin \& Arifin (2012) menyatakan bawha perubahan tarif pajak penghasilan badan berpengaruh negatif terhadap harga saham walaupun selanjutnya harga saham mengalami penurunan akibat gejala overreaction di pasar modal. Mungkin terdapat variabel lain yang mampu mempengaruhi return saham seperti yang disampaikan Putra \& Tjaraka (2016) dalam penelitiannya yang menunjukkan bahwa perubahan tarif pajak penghasilan badan tidak berpengaruh signifikan terhadap return saham. Harga saham yang terbentuk dari aktivitas investasi atau trading yang dilakukan oleh investor dapat diamati melalui trading volume activity. Aktivitas volume perdagangan menggambarkan jumlah saham yang ditawarkan dan jumlah saham yang terjual. Banyaknya investor yang memilih untuk menjual sahamnya akan mempengaruhi keputusan yang akan diambil oleh investor lainnya. Hal ini dikarenakan pemahaman yang dimiliki oleh investor bahwa bila banyak investor lain yang memilih untuk menjual suatu saham, maka prospek kedepan yang dimiliki oleh perusahaan tersebut dapat dipertanyakan. Hukum permintaan dan penawaran menjelaskan bila saham yang ditawarkan banyak dan penawaran akan saham itu sedikit, maka harga dari saham tersebut akan menurun. Sebaliknya, bila saham yang ditawarkan sedikit sedangkan permintaannya banyak, maka saham tersebut akan mengalami peningkatan harga. Besar kecilnya penawaran dan permintaan saham dipengaruhi oleh harapan akan hasil yang diterima dikemudian hari oleh investor. Volume perdagangan dapat digunakan untuk mengidentifikasi keadaan volatilitas di saham masa depan (Koubaa \& Slim, 2019). Berdasarkan uraian ini, maka trading volume activity dimasukkan sebagai variabel yang diharapkan mampu memediasi hubungan return saham yang dipengaruhi oleh perubahan tarif pajak penghasilan badan. Kondisi ini sejalan dengan penelitian Aprisilya dan Mawardi (2016) yang menunjukkan TVA dapat digunakan sebagai variabel intervening karena berpengaruh positif signifikan memediasi hubungan return ekspektasian. Berhasilnya mediasi TVA terhadap 
return saham juga ditunjukkan oleh penelitian Khaddaf et al (2014). Berdasarkan kondisi ini, maka hipotesis yang dapat diambil adalah.

$\mathrm{H}_{4}$ : Trading volume activity memediasi atau mampu menjadi variabel intervening pengaruh antara perubahan tarif pajak penghasilan badan dan return saham.



Gambar 1. Model Peneltian

Sumber: Data Penelitian, 2020

\section{METODE PENELITIAN}

Pajak penghasilan badan merupakan salah satu pajak yang harus dibayarkan oleh wajib pajak badan. Sebagai alat untuk mengukur besarnya pajak yang harus dibayarkan oleh wajib pajak maka diterapkanlah tarif pajak. Perubahan tarif pajak penghasilan badan sebagai varibel independen diukur dengan menggunakan variabel dummy dimana angka 0 menunjukkan tarif pajak penghasilan badan sebelum terjadinya perubahan dan angka 1 menunjukkan tarif pajak penghasilan badan setelah terjadinya perubahan. Return saham merupakan hasil atau pengembalian dari transaksi yang dilakukan dengan menjual maupun membeli saham. Variabel return saham diukur dengan menggunakan return total. Return total adalah pengukuran dengan membandingkan harga saham periode sekarang dengan harga saham sebelum periode sekarang. Trading volume activity atau volume perdagangan yakni banyaknya saham perlembar yang diperjual belikan di pasar modal setiap hari kerja bursa. Besarnya volume perdagangan dihitung dari jumlah saham yang diperdagangkan dalam periode tertentu dibagi dengan jumlah saham yang beredar atau listing (Wardhani, 2012).

Metode pengumpulan data merupakan suatu teknik atau cara yang digunakan dalam pengumpulan data. Data yang dikumpulkan berasal dari data sekunder yang merupakan data yang telah ada dan tidak perlu dikumpulkan sendiri berupa laporan keuangan dan harga saham. Data-data yang digunakan diperoleh dengan mengakses situs resmi Bursa Efek Indonesia yang dapat disebut sebagai dataset statistik dengan metode pengumpulan data dokumentasi. Dataset statistik merupakan data yang telah dikumpulkan oleh pihak ke-tiga yang memiliki otoritas, sedangkan dokumentasi ialah catatan sebuah peristiwa yang sudah lampau.

Populasi adalah wilayah generalisasi yang terdiri atas objek atau subyek yang mempunyai kualitas dan karakteristik tertentu yang ditetapkan untuk dipelajari dan kemudian ditarik simpulannya (Sugiyono, 2017:135). Seluruh perusahaan yang terdaftar di Bursa Efek Indonesia pada tahun 2020 yang berjumlah 693 
perusahaan menjadi wilayah generalisasi penelitian. Sampel adalah bagian dari jumlah dan karakteristik yang dimiliki oleh populasi (Sugiyono, 2017:136). Dari pengertian yang dijelaskan oleh sugiyono dapat diartikan bahwa sampel merupakan bagian dari populasi dimana sampel merupakan bagian terpilih dari populasi yang diteliti. Sampel yang digunakan adalah populasi yang telah memenuhi kriteria pemilihan sampel. Kriteria yang harus dimiliki oleh sampel agar tidak menyebabkan hasil penelitian bias adalah perusahaan Go Public yang telah terdaftar pada Bursa Efek Indonesia dan perusahaan termasuk kedalam indeks LQ45. Indeks LQ45 dipilih karena perusahaan yang termasuk ke dalam indeks tersebut memiliki saham yang paling banyak diminati oleh investor sehingga informasi perubahan tarif pajak penghasilan badan akan menimbulkan reaksi yang mampu menggambarkan kondisi pasar modal. Selain itu, perusahaan yang tergolong kedalam indeks LQ45 memiliki tingkat likuiditas dan kapitalisasi yang besar sehingga dapat dijadikan sebagai dasar untuk menilai naik turunnya harga saham di Bursa Efek Indonesia. Perusahaan yang memiliki kapitalisasi besar akan mengalami dampak yang lebih signifikan bila dibandingkan dengan perusahaan yang memiliki kapitalisasi kecil dari adanya perubahan tarif pajak penghasilan badan.

Teknik analisis jalur yang dibantu oleh pengujian langsung dan tak langsung dilakukan untuk mengetahui korelasi masing-masing variabel yang digunakan. Analisis jalur menggunakan metode regresi bertahap yakni untuk regresi model 1 dan regresi model 2 dengan rumus.

Model 1: $Z=\alpha+\beta 1 X 1+\varepsilon$.

Model 2: $Y=\alpha+\beta 1 X 1+\beta 2 Z 2+\varepsilon$

Untuk menguji signifikansi hubungan tidak langsung antara variabel independen dengan variabel dependen yang dimediasi oleh variabel trading volume activity, maka Uji Sobel dilakukan sebagai pengujian akhir.

\section{HASIL DAN PEMBAHASAN}

Tabel 1. Hasil Uji Analisis Jalur

\begin{tabular}{|c|c|c|c|c|c|c|}
\hline & & \multicolumn{2}{|c|}{$\begin{array}{l}\text { Unstandardized } \\
\text { Coefficients }\end{array}$} & \multirow{2}{*}{$\begin{array}{c}\begin{array}{c}\text { Standardized } \\
\text { Coefficients }\end{array} \\
\text { Beta }\end{array}$} & \multirow[b]{2}{*}{$\mathrm{T}$} & \multirow[b]{2}{*}{ Sig. } \\
\hline & & B & Std. Error & & & \\
\hline \multirow{3}{*}{$\begin{array}{l}\text { Model } \\
\text { I }\end{array}$} & (Constant) & $-0,205$ & 0,087 & & $-2,363$ & 0,018 \\
\hline & $\begin{array}{l}\text { Perubahan Tarif } \\
\text { PPh Badan }\end{array}$ & 0,181 & 0,067 & 0,120 & 2,679 & 0,008 \\
\hline & (Constant) & $-0,045$ & 0,006 & & $-6,883$ & 0,000 \\
\hline \multirow{4}{*}{$\begin{array}{l}\text { Model } \\
\text { II }\end{array}$} & $\begin{array}{l}\text { Perubahan Tarif } \\
\text { PPh Badan }\end{array}$ & 0,030 & 0,005 & 0,233 & 5,552 & 0,000 \\
\hline & $\begin{array}{l}\text { Trading Volume } \\
\text { Activity }\end{array}$ & 3,196 & 0,470 & 0,285 & 6,801 & 0,000 \\
\hline & ANOVA & $=0,000$ & & & & \\
\hline & $\begin{array}{l}\mathrm{R}^{2} \\
\text { Adjusted R } \\
\text { Square }\end{array}$ & $\begin{array}{l}=0,137 \\
=0,133\end{array}$ & & & & \\
\hline
\end{tabular}

Sumber: Data Penelitian, 2020 
Berdasarkan tabel Hasil Uji Analisis Jalur Pada Regresi Model 1 dan Hasil Uji Analisis Jalur Pada Regresi Model 2, maka persamaan regresi yang digunakan yakni sebagai berikut.

Model 1: $Z=-0.205+0.181 X$

Model 2: $Y=-0.045+0.030 X+3.196 Z$

Hubungan atau korelasi antara variabel perubahan tarif pajak penghasilan badan dan trading volume activity terhadap return saham pada Regresi Model 2 dapat dilihat melalui Tabel Hasil Uji Analisis Jalur. Nilai $R$ Square sebesar 0,137 atau 13,7 persen dapat menjelaskan bahwa korelasi antara variabel yang digunakan dalam penelitian ini tergolong redah atau dapat diabaikan. Return saham dapat dijelaskan oleh variabel perubahan tarif pajak penghasilan badan dan trading volume activity sebesar 13,7 persen sedangkan 86,3 persen dipengaruhi oleh faktor lain yang tidak dimasukkan ke dalam model penelitian.

Pengaruh perubahan tarif pajak penghasilan badan dan trading volume activity secara simultan terhadap return saham dapat diamati melalui tabel ANOVA Hasil Uji Analisis Jalur pada Regresi Model 2. Nilai signifikansi menunjukkan angka sebesar 0,000 $<5$ persen menjelaskan bahwa variabel independen secara bersama-sama berpengaruh terhadap variabel dependen. Hubungan langsung dan tidak langsung antara variabel independen (perubahan tarif pajak penghasilan badan) dengan variabel dependen (return saham) yang dimediasi oleh variabel trading volume activity dapat dilihat melalui Tabel 2 dan 3. Tabel 2. Pengujian Pengaruh Langsung

\begin{tabular}{|c|c|c|c|c|}
\hline & Lintasan $($ Path $)$ & Koefisien & Signifikansi & Keterangan \\
\hline & $\rightarrow Z$ & 0,181 & 0,008 & Berpengaruh langsung \\
\hline$X$ & $\rightarrow \mathrm{Y}$ & 0,030 & 0,000 & Berpengaruh langsung \\
\hline Z & $\rightarrow Y$ & 3,196 & 0,000 & Berpengaruh langsung \\
\hline
\end{tabular}

Sumber: Data Penelitian, 2020

Berdasarkan Tabel 2, tentang pengujian pengaruh langsung, nilai signifikansi seluruh variabel menunjukkan angka $<5$ persen yang berarti bahwa perubahan tarif pajak penghasilan badan memiliki pengaruh langsung terhadap trading volume activity sebesar 0,181 serta perubahan tarif pajak penghasilan badan dan trading volume activity memiliki pengaruh langsung terhadap return saham secara berturut sebesar 0,030 dan 3,196.

Tabel 3. Pengujian Pengaruh Tidak Langsung

\begin{tabular}{cccc}
\hline $\begin{array}{c}\text { Lintasan } \\
(\text { Path })\end{array}$ & $\begin{array}{c}\text { Pengaruh } \\
\text { Langsung }\end{array}$ & $\begin{array}{c}\text { Pengaruh Tidak } \\
\text { Langsung }\end{array}$ & $\begin{array}{c}\text { Pengaruh } \\
\text { Total }\end{array}$ \\
\hline $\mathrm{X} \rightarrow \mathrm{Z} \rightarrow \mathrm{Y}$ & 0,030 & 0,578 & 0,608 \\
\hline
\end{tabular}

Berdasarkan Tabel 3, tentang pengujian pengaruh tidak langsung, diperoleh nilai pengaruh langsung sebesar 0.030 lebih kecil dari pengaruh tidak langsung dengan nilai 0,578 yang bermakna bahwa secara tidak langsung perubahan tarif pajak penghasilan badan melalui trading volume activity memiliki pengaruh signifikan yang lebih besar terhadap return saham. 
Tabel 4. Hasil Uji Sobel

\begin{tabular}{llllll}
\hline & Input & & Test Statistic & Std. Error & P value \\
\hline A & 0,181 & Sobel test & 2,510 & 0,230 & 0,012 \\
B & 3,196 & Aroian test & 2,487 & 0,232 & 0,012 \\
Sa & 0,067 & Godman test & 2,534 & 0,228 & 0,011 \\
Sb & 0,470 & & & & \\
\hline
\end{tabular}

Sumber: Data Penelitian, 2020

Angka yang menunjukkan nilai 0,008 $<5$ persen pada Tabel 4 . Hasil Uji Analisis Jalur pada Regresi Model I bermakna bahwa perubahan tarif pajak penghasilan badan berpengaruh secara signifikan terhadap trading volume activity, sedangkan coefficients nilai beta bernilai positif sebesar 0,181 memiliki arti bahwasanya perubahan tarif pajak penghasilan badan berpengaruh positif terhadap trading volume activity. Variabel perubahan tarif pajak penghasilan badan memiliki pengaruh positif terhadap return saham. Hal ini dapat diamati melalui tabel Hasil Uji Analisis Jalur pada Regresi Model II. Nilai signifikasi perubahan tarif pajak penghasilan badan sebesar $0,000<5$ persen serta nilai beta yang memiliki besaran positif dengan angka 0,030 memiliki makna bahwa perubahan tarif pajak penghasilan badan memiliki pengaruh positif terhadap return saham. Variabel trading volume activity memiliki pengaruh positif terhadap return saham. Hal ini dapat diamati melalui tabel Hasil Uji Analisis Jalur pada Regresi Model II. Nilai signifikasi trading volume activity sebesar $0,000<5$ persen serta nilai beta yang memiliki besaran positif dengan angka 3,196 memiliki makna bahwa trading volume activity memiliki pengaruh positif terhadap return saham. Hasil dari pengujian langsung dan tidak langsung pada Tabel 2 dan 3 menunjukkan bahwa secara tidak langsung perubahan tarif pajak penghasilan badan melalui trading volume activity memiliki pengaruh signifikan yang lebih besar terhadap return saham dengan nilai koefisien pengaruh tidak langsung dan langsung sebesar 0,578 $>0,030$, diperkuat lagi dengan hasil Uji Sobel pada Tabel 4, yang menunjukkan nilai sebesar 2,510 > 1,96 yang berarti bahwa trading volume activity berhasil menjadi mediator hubungan perubahan tarif pajak penghasilan badan dengan return saham.

\section{SIMPULAN}

Dalam Kamus Besar Bahasa Indonesia (KBBI) dijelaskan bahwa simpulan merupakan keputusan yang diperoleh berdasarkan pada uraian yang telah dibahas sebelumnya. Adapun simpulan dari penelitian ini, Perubahan tarif pajak penghasilan badan berpengaruh positif terhadap trading volume activity, Trading volume activity berpengaruh positif terhadap return saham, Perubahan tarif pajak penghasilan badan berpengaruh positif terhadap return saham, dan Trading volume activity mampu menjadi variabel mediasi hubungan perubahan tarif pajak penghasilan badan terhadap return saham.

Berdasarkan pada hasil penelitian yang telah dirangkum dalam simpulan diatas, serta dalam rangka pengembangan dan penyempurnaan hasil penelitian, maka dikemukakan saran. Memperpanjang event period atau periode pengamatan menjadi dalam bulanan dan memperluas sampel penelitian dengan menambahkan sektor manufaktur agar hasil yang didapatkan dapat digunakan untuk membandingkan hasil penelitian serta menggambarkan peristiwa yang 
terjadi secara lebih spesifik dan Hubungan antar variabel yang rendah dalam penelitian ini mengindikasikan bahwa penelitian ini belum cukup untuk memberikan bukti mengenai pendapat teoritis yang dipaparkan. Oleh karena itu, penelitian selanjutnya diharapkan dapat memperbaikinya dengan memilih variabel penelitian lain seperti ukuran perusahaan sebagai variabel kontrol atau memilih model pengukuran untuk variabel perubahan tarif pajak penghasilan badan yang lebih sesuai.

\section{REFERENSI}

Ady, S. U. (2017). Eksplorasi Tingkat Efisiensi Pasar Modal Indonesia Studi Kasus Di Bursa Efek Indonesia. Ekspektra: Jurnal Bisnis Dan Manajemen, 1(2), 103.

Ahmad Taslim, A. W. (2016). Pengaruh Frekuensi Perdagangan Saham, Volume Perdagangan Saham, Kapitalisasi Pasar dan Jumlah Hari Perdagangan Terhadap Return Saham. Management Analysis Journal, 5(1), 5.

Amiruddin, A., \& Arifin, Z. (2012). Pengaruh Perubahan Undang-Undang Pajak Penghasilan Tahun 2008 Terhadap Harga Saham Dan Kebijakan Dividen. Sinergi, 13(1), 70-77. Https://Doi.Org/10.20885/Sinergi.Vol13.Iss1.Art6

Aprisilya, T. (2016). Analisis Pengaruh Total Asset Turnover, Book To Market Ratio, Debt Equity Ratio Terhadap Expected Return Dengan Trading Volume Activity Sebagai Variabel Intervening (Studi Pada Perusahaan Perbankan Yang Terdaftar Pada BEI Periode 2011-2014). 5, 1-14.

Ariyani Indriastuti B. Zumrotun. (2017). Pengaruh Volume Perdagangan, Kurs Dan Risiko Pasar Terhadap Return Saham. Jurnal STIE Semarang. Vol. 9. No. 1.

Blouin, J. L., Fich, E. M., Rice, E. M., \& Tran, A. L. (2020). Corporate Tax Cuts, Merger Activity, And Shareholder Wealth. In Journal Of Accounting And Economics. Https://Doi.Org/10.1016/J.Jacceco.2020.101315

Boonvorachote, T., \& Lakmas, K. (2016). Price Volatility, Trading Volume, And Market Depth In Asian Commodity Futures Exchanges. Kasetsart Journal Of Social Sciences, 37(1), 53-58. Https://Doi.Org/10.1016/J.Kjss.2016.01.004

Chaslim, M., \& Meiden, C. (2018). Relevansi Nilai Informasi Akuntansi Terhadap Harga Saham Yang Dimoderasi Konservatisme Akuntansi. Akuntansi Keuangan \& Pasar Modal, 7(2), 179-203.

Dai, Z., Zhou, H., Wen, F., \& He, S. (2020). Efficient Predictability Of Stock Return Volatility: The Role Of Stock Market Implied Volatility. North American Journal Of Economics And Finance, 52(July 2019), 101174. Https:/ /Doi.Org/10.1016/J.Najef.2020.101174

Dai, Z., \& Zhu, H. (2020). Stock Return Predictability From A Mixed Model Perspective. Pacific Basin Finance Journal, 60, 101267. Https://Doi.Org/10.1016/J.Pacfin.2020.101267

Delgado, F. J., Fernández-Rodríguez, E., Martínez-Arias, A., \& Presno, M. J. (2019). Club Convergence In The Corporate Income Tax: The Case Of European Effective Rates. Physica A: Statistical Mechanics And Its Applications, 523, 942953. Https://Doi.Org/10.1016/J.Physa.2019.04.212

Gary, R. F., Moore, J. A., Sisneros, C. A., \& Terando, W. D. (2016). The Impact Of Tax Rate Changes On Intercorporate Investment. Advances In Accounting, 34, 55-63. Https://Doi.Org/10.1016/J.Adiac.2016.07.002 
Gumanti, T. A., \& Utami, E. S. (2002). Bentuk pasar efisien dan pengujiannya.

Hayashida, M., \& Ono, H. (2016). Tax Reforms And Stock Return Volatility: The Case Of Japan. Journal Of Asian Economics, 45, 1-14. Https:/ Doi.Org/10.1016/J.Asieco.2016.04.002

Heyden, K. J., \& Heyden, T. (2020). Market Reactions To The Arrival And Containment Of COVID-19: An Event Study. SSRN Electronic Journal, 101745. Https://Doi.Org/10.2139/Ssrn.3587497

I Gst Agung A. Densi Wulandari, Made Arie Wahyuni, E. S. (2017). Reaksi Investor Dalam Pasar Modal Terhadap Undang-Undang Tax Amnesty (Event Study Pada Perusahaan Yang Terdaftar Dalam LQ45 Di Bursa Efek Indonesia). JIMAT (Jurnal Ilmiah Mahasiswa Akuntansi) Undiksha, 7(1). Https://Doi.Org/10.23887/Jimat.V7i1.9504

Kamus Besar Bahasa Indonesia. Diakses melalui aplikasi KBBI EDISI V.

Khaddaf, M., . K. A. F., \& . R. (2014). The Effect Of Earnings Aggressiveness, Earnings Smoothing On Return Of Stock. Journal Of Economics And Behavioral Studies, 6(6), 509-523. Https:// Doi.Org/10.22610/Jebs.V6i6.512

Koubaa, Y., \& Slim, S. (2019). The Relationship Between Trading Activity And Stock Market Volatility: Does The Volume Threshold Matter? Economic Modelling, 82(April 2018), 168-184.

Https:/ /Doi.Org/10.1016/J.Econmod.2019.01.003

Munthe, K. (2017). Perbandingan Abnormal Return Dan Likuditas Saham Sebelum Dan Sedudah Stock Split: Studi Pada Perusahaan Yang Terdaftar Di Bursa Efek Indonesia. Jurnal Akuntansi, 20(2), 254. Https:/ /Doi.Org/10.24912/Ja.V20i2.57

Peraturan Pemerintah Pengganti Undang-Undang No. 1 Tahun 2020. Tentang Kebijakan Keuangan Negara Dan Stabilitas Sistem Keuangan Untuk Penanganan Pandemi Corona Virus Disease 2019 (Covid- 19) Dan/Atau Dalam Rangka Menghadapi Ancaman Yang Membahayakan Perekonomian Nasional Dan/Atau Stabilitas Sistem Keuangan. (2020). Indonesia.

Pham, A. (2020). Effects Of Temporary Corporate Income Tax Cuts: Evidence From Vietnam. Journal of Development Economics, 146, 102476. Https:/ /Doi.Org/10.1016/J.Jdeveco.2020.102476

Putra, G. R., \& Tjaraka, H. (2016). Pengaruh Perubahan Tarif Pajak Penghasilan Badan Terhadap Return Saham Dengan Liabilitas Pajak Tangguhan Sebagai Variabel Intervening Pada Perusahaan Manufaktur Yang Terdaftar di BEI (Periode 2008 - 2010). Infestasi, $12(1), \quad 98$. Https:/ / Doi.Org/10.21107/Infestasi.V12i1.1804

Putri, W. A. (2017). Insentif Pajak Dalam Membentuk Keputusan Investasi. Moneter, 4 No 2(2), 1-7. Retrieved From Https:/ /Ejournal.Bsi.Ac.Id/Ejurnal/Index.Php/Moneter/Article/View/24 45

Rzayev, K., \& Ibikunle, G. (2019). A State-Space Modeling Of The Information Content Of Trading Volume. Journal Of Financial Markets, 46(Xxxx), 100507. Https:/ / Doi.Org/10.1016/J.Finmar.2019.100507

Sari, A. N. E. (2013). Universitas Bakrie. 3(1), 1.

Sugiyono. (2017). Statistik Untuk Penelitian (9th Ed.). Bandung: Alfabet.

Wardhani, L. S. (2012). Reaksi Pasar Modal Indonesia Terhadap Peristiwa 
Pemilihan Gubernur DKI Jakarta Putaran II 2012. Jurnal Ilmiah Mahasiswa Fakultas Ekonomi Dan Bisnis Universitas Brawijaya, 1(1). Retrieved From Www.Academia.Edu/Download/35572678/Main_Journal.Pdf

Xu, L., Gao, H., Shi, Y., \& Zhao, Y. (2020). The Heterogeneous Volume-Volatility Relations In The Exchange-Traded Fund Market: Evidence From China. Economic Modelling, 85(July 2019), 400-408. Https://Doi.Org/10.1016/J.Econmod.2019.11.019

Xu, Z., Chevapatrakul, T., \& Li, X. (2019). Return Asymmetry And The Cross Section Of Stock Returns. Journal Of International Money And Finance, 97, 93110. Https://Doi.Org/10.1016/J.Jimonfin.2019.06.005

Zhang, Y., Wei, Y., Ma, F., \& Yi, Y. (2019). Economic Constraints And Stock Return Predictability: A New Approach. International Review Of Financial Analysis, 63(November 2018), 1-9. Https://Doi.Org/10.1016/J.Irfa.2019.02.007 